Whole-Building Systems

Integration Laboratory Survey

Survey of Engineering

School Faculty

September 1989

Prepared by Research \& Management Foundation, American Consulting Engineers Council, for Pacific Northwest Laboratory under Contract DE-AC06-76RLO 1830

with the U.S. Department of Energy

Pacific Northwest Laboratory Operated for the U.S. Department of Energy by Battelle Memorial Institute 


\title{
DISCLAIMER
}

This program was prepared as an account of work sponsored by an agency of the United States Government. Neither the United States Government nor any agency thereof, nor Battelle Memorial Institute, nor any or their employees, makes any warranty, expressed or implied, or assumes any legal liability or responsibility for the accuracy, completeness, or usefulness of any information, apparatus, product, or process disclosed, or represents that its use would not infringe privately owned rights. Reference herein to any specific commercial product, process, or service by trade name, trademark, manufacturer, or otherwise, does not necessarily constitute or imply its endorsement, recommendation, or favoring by the United States Government of any agency thereof, or Battelle Memorial Institute. The views and opinions of authors expressed herein do not necessarily state or reflect those of the United States Government or any agency thereof.

\author{
PACIFIC NORTHWEST LABORATORY \\ operated by \\ BATTELLE MEMORIAL INSTITUTE \\ for the \\ UNITED STATES DEPARTMENT OF ENERGY \\ under Contract DE-AC06-76RLO 1830
}

\author{
Printed in the United States of America
}

Available to DOE and DOE contractors from the

Office of Scientific and Technical Information, P.O. Box 62, Oak Ridge, TN 37831; prices available from (615) 576-8401. FTS 626-8401.

Available to the public from the National Technical Information Service, U.S. Department of Commerce, 5285 Port Royal Rd., Springfield, VA 22161.

NTIS Price Codes, Microfiche A01

Printed Copy

$\begin{array}{ccc}\frac{c}{\text { Pages }} & \begin{array}{c}\text { Price } \\ \text { Codes }\end{array} \\ 026-025 & & \text { A02 } \\ 051-075 & & \text { A03 } \\ 076-100 & & \text { A04 } \\ 101-125 & \text { A05 } \\ 126-150 & \text { A06 } \\ 151-175 & \text { A07 } \\ 176-200 & \text { A08 } \\ 201-225 & \text { A09 } \\ 226-250 & \text { A10 } \\ 251-275 & \text { A11 } \\ 276-300 & \text { A12 } \\ & \text { A13 }\end{array}$


WHOLE-BUILDING SYSTEMS INTEGRATION

LABORATORY SURVEY

SURVEY OF ENGINEERING SCHOOL FACULTY

Research \& Management Foundation, American Consulting Engineers Council Washington, D.C.

D. B. Crawley, PNL Project Manager

September 1989

Prepared by the Research \& Management Foundation, American Consulting Engineers Council, for Pacific Northwest Laboratory under Contract DE-AC06-76RL0 1830 with the U.S. Department of Energy under Agreement B-V1903-A-N

Pacific Northwest Laboratory Richland, Washington 99352 


\section{PROJECT PERSPECTIVE}

This report was prepared for the Pacific Northwest Laboratory as a subcontracted activity by the Research \& Management Foundation of the American Consulting Engineers Council. The objective of the survey reported herein was to independently assess the need for a Building System Integration Laboratory from the viewpoint of academicians in the field of building science. The subcontractor-developed questionnaire was sent to 200 professors of architecture and engineering at U.S. universities. In view of this diverse population, the $10 \%$ rate of return on the questionnaire was considered acceptable. Although the responses probably do not reflect an unbiased summary of the collective perceptions of the original population surveyed, they do provide a valid insight into the interests and concerns of the academic community with respect to building sciences issues. 


\section{CONTENTS}

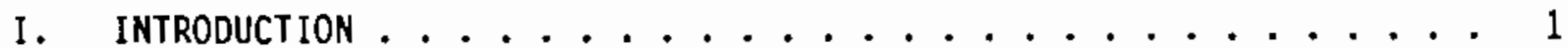

II. THE SURVEY QUESTIONS .................... 2

III. BUILOING ENERGY RESEARCH . . . . . . . . . . . . . 3

IV. AVAILABLE PHYSICAL faCILITIES ................ 4

V. VALUE OF UNIVERSITY FACILITIES AND EQUIPMENT

AND NUMBER OF PERSONNEL ................. 6

VI. MAJOR SUPPORTERS OF RESEARCH .............. 7

VII. IMPORTANCE OF OPTIONS $1-4 \ldots \ldots \ldots$

APPENDIX A - SURVEY FORM .................. 14

APPENDIX B - EQUIPMENT AVAILABLE AT UNIVERSITIES . . . . . . . 19

APPENDIX C - BRIEF TITLE OF RECENTLY COMPLETED PROJECTS

AND FUNDING LEVEL ...............20

APPENDIX D - BRIEF tITLE OF CURRENT PROJECTS AND FUNDING LEVEL. . . . . 20

APPENDIX E - BRIEF TITLE OF FUTURE PROJECTS AND FUNDING LEVEL . . . . . 21 


\section{FIGURES}

1 Value of Building Energy Research in Respondents' Departments. . . . 3

2 Value of Buitding Energy Research at Respondents' Universities . . . 3

3 University Test Facilities--Controlled Environments . . . . . . . 4

4 University Test Facilities--Controllable Environment . . . . . . 4

5 University Test Facilities--Standard Laboratory Space . . . . . . 5

6 University Test Facilities--Open Area . . . . . . . . . . 5

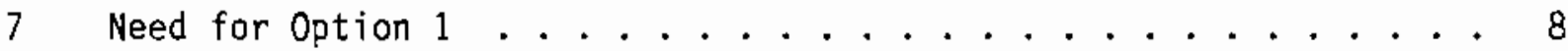

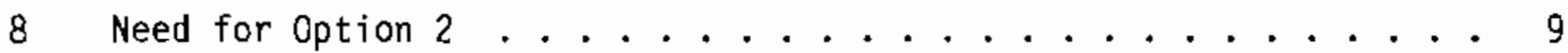

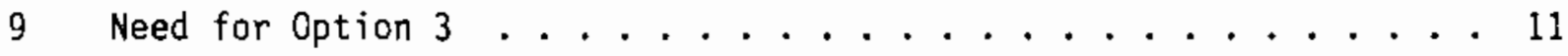

10 Need for Option 4 . . . . . . . . . . . . . 12

\section{$\underline{\text { TABLES }}$}

I Building Research Personnel at Universities . . . . . . . . 6

II Research Sponsors and Level of Support . . . . . . . . . . . 7

IIIa Option 1 Fuel Savings . . . . . . . . . . . . . . . . 8

Il Ib Option 1 Fuel Savings . . . . . . . . . . . . . . . . . 9

IVa option 2 fuel Savings . . . . . . . . . . . . . . . 10

IVb Option 2 Fuel Savings . . . . . . . . . . . . . . . 10

Va Option 3 Fuel Savings . . . . . . . . . . . . . . . . . 11

Vo option 3 Fuel Savings . . . . . . . . . . . . . . . . 11

VIa Option 4 fuel Savings . . . . . . . . . . . . . . . . . 12

VIb Option 4 fuel Savings . . . . . . . . . . . . . . . . . 13 


\title{
Whole-Building Systems Integration Laboratory Survey
}

\author{
SURVEY OP ENGINEERING FACULTY
}

\section{INTRODUCTION}

During May and June of 1988, ACEC Research \& Management Foundation (ACEC/RMF) conducted a survey of the over 200 engineering professors who had participated in one or more of the annual ACEC/RMF Institute on Energy and Engineering Education. The purpose of this survey was to assist Battelle Pacific Northwest Laboratories (PNL) in determining the need for a whole-building systems integration laboratory (WBSIL). The laboratory, if founded, will investigate energy flows arising from the interactions of building systems design and use. This information as well as that developed from other surveys and workshops will be presented to the Department of Energy to provide an informed basis for decisions on a whole-building systems integration laboratory.

The respondents were provided with a two-page letter explaining the questionnaire, its purpose and the background.

The survey form is illustrated in Appendix A. For most questions, respondents were asked to check the appropriate box. This format was chosen so that questions would be easy to answer and would provide consistency (categorically) so that inferences could be drawn. A comment line was included so that those who wished could express an opinion not reflected by the choices. These free-form comments added a depth and flavor that cannot be captured otherwise.

The respondents were asked to respond by mid June. This report is the results of the survey.

\section{Why Establish a Laboratory?}

The whole-building systems integration laboratory would be dedicated to the investigation of commercial whole-building and system-integration issues. Commercial buildings account for over 15 percent of the fossil fuel energy used in the United States. Economies realized in this sector could significantly affect the vulnerability of the United States in any future imported fuel shortage.

The working hypothesis is that there is a need for specific facilities and coordination activities to increase the effectiveness and use of completed, ongoing, and future building energy research.

A committee of experts convened by PNL concluded that a WBSIL could work in two distinct areas:

- Testing known unknowns to incrementally improve existing building assemblies and concepts.

- Testing unknown unknowns to develop new building concepts. In the latter case this may be working towards a "zero-fossil-fuels" integrated systems building.

The PNL committee has proposed four alternative options to achieve the envisioned purpose, based on the pros and cons in terms of money, time, critical questions, effective results, increase in U.S. competitiveness and professionalism: 
Option 1. A center that would primarily coordinate information about whole-building system integration with minimal or no test facilities. The center would rely on the third and fourth options below. Test facilities-Option 2 is an example-would be added as critical research questions became focused.

Option 2. A three-story, 30,000 s.f. facility within an environmental chamber that could be removed to expose test floors to the local elimate conditions.

Option 3. Lease or purchase of buildings or floors in commercial buildings around the country for limited periods that could be instrumented and staffed by universities and private and federal laboratories and used as a lab facility.

Option 4. Use of existing facilities, public or private, that could be enhanced if necessary to provide the whole-building system integration features needed.

\section{Respondeats}

Twenty respondents-10 percent-replied out of the mailing of 200 , a high rate.

The interest in whole-building systems integration research on the part of the university community is expressed in the following responses.

$\begin{array}{lc}\text { Very } & 50 \% \\ \text { Moderately } & 25 \% \\ \text { Keep me informed } & 25 \% \\ \text { Not Interested } & 0 \%\end{array}$

In the field of whole-building systems integration research the respondents' self-evaluated level of knowledge/expertise level is:

$\begin{array}{lr}\text { Expert } & 40 \% \\ \text { Journeyman } & 40 \% \\ \text { Apprentice } & 5 \% \\ \text { Beginner } & 10 \%\end{array}$

\section{THE SURVEY QUESTIONS}

The survey was divided into two parts. The first determined the extent of existing and planned facilities on U.S campuses as well as personnel engaged in research, major funding sources, and the respondents' expertise in energy matters. The second elicited opinions concerning the importance of a whole-building research effort in the four options discussed above. 


\section{ButLdNG ENERgy Researci}

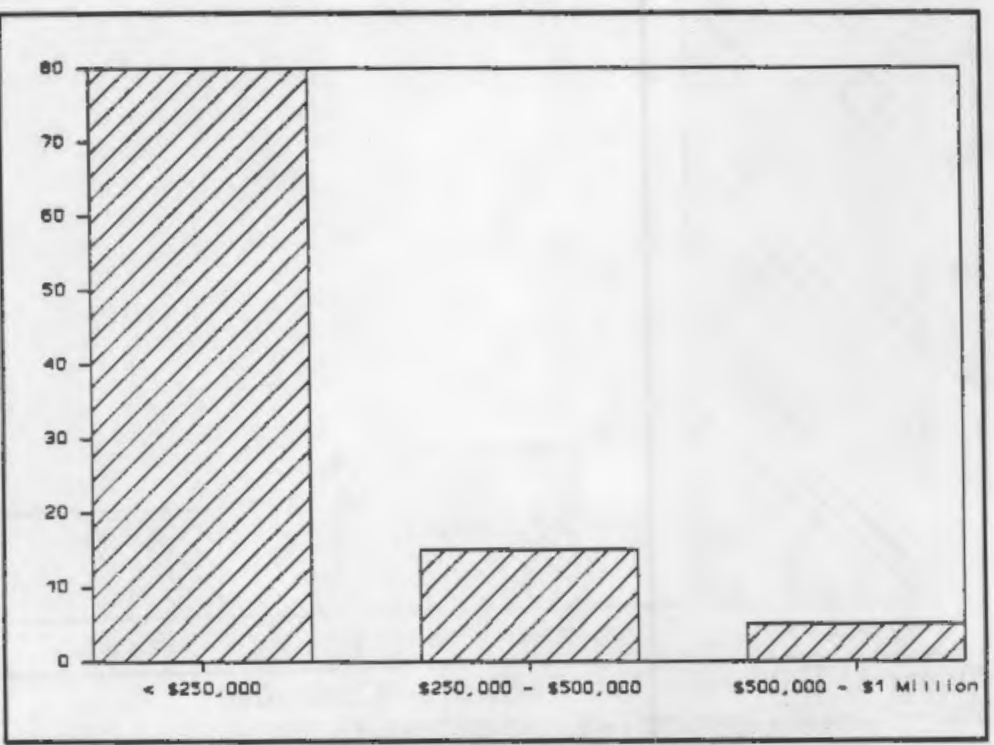

Respondents were asked to estimate the total value of building energy research projects that the respondent's department performs annually. See Figure 1. This skew towards small amounts (and therefore small projects) suggests that while the base for research is broad, problems being investigated may be specific and not leading to answers that a WBSIL could provide.

Figure 1. Value of Building Energy Research in Respondents' Departments (percent of respondents)

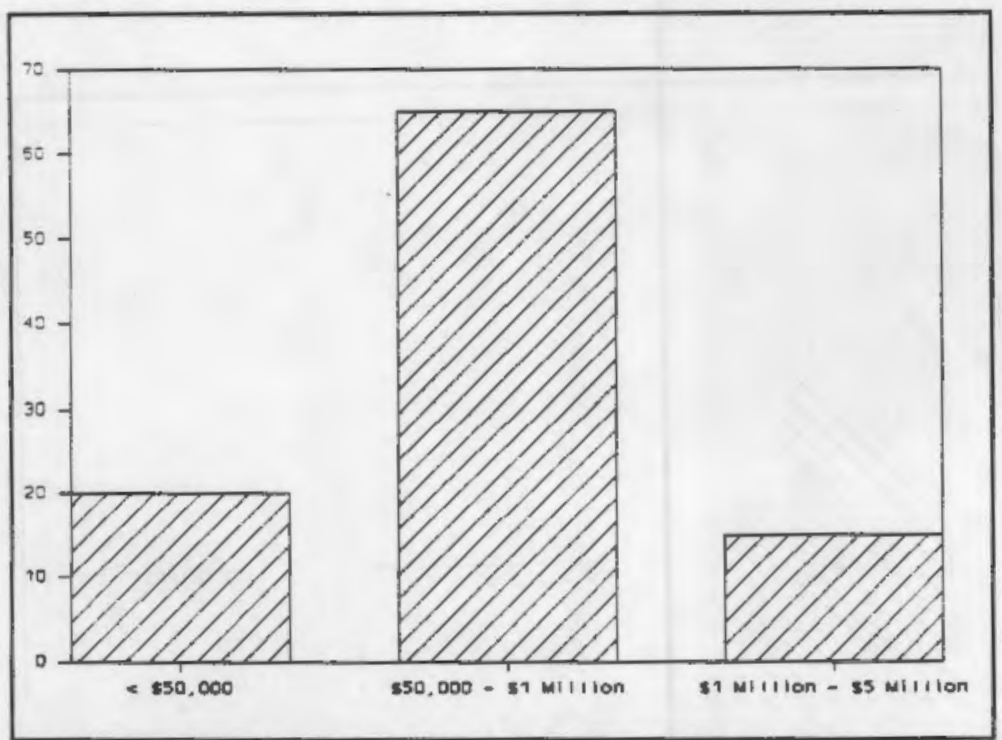

An estimate of the total value of building energy research projects that the respondent's university as a whole performs confirmed the answers regarding research at the departmental level. The range was broadened but yieided the same general percentages. See Figure 2.

Figure 2. Value of Building Energy Research at Respondents' Universities (percent of respondents) 


\section{Avam.able Pgysical fachities}

Respondents were asked to describe the square footage of various test facilities to determine if they were, or could be, equipped for whole-building systems testing. Figures 3-6 are for different types of environments.

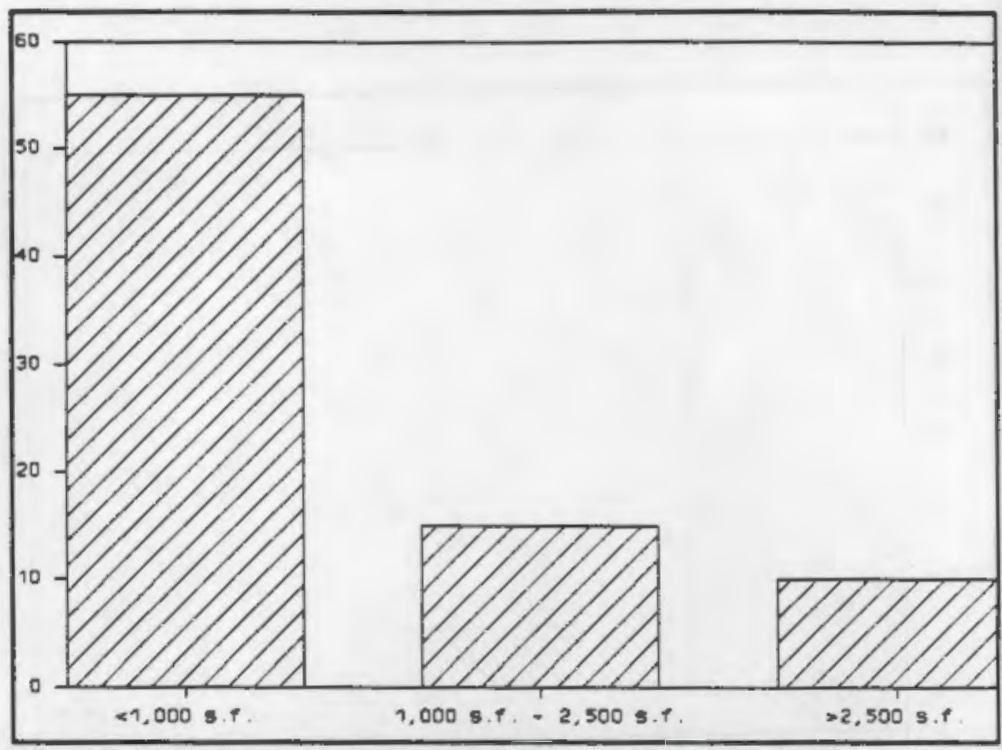

Figure 3. University Test Facilities-Controlled Environments (percent of respondents)
These figures suggest that individual universities do not have facilities on the scale proposed in Option 2 (a three-story, 30,000.s.f. facility within an environmental chamber). They do have the capability to mount modest integrated experiments. These would support Option 1 (a center that would primarily coordinate information about whole-building system integration with minimal or no test facilities).

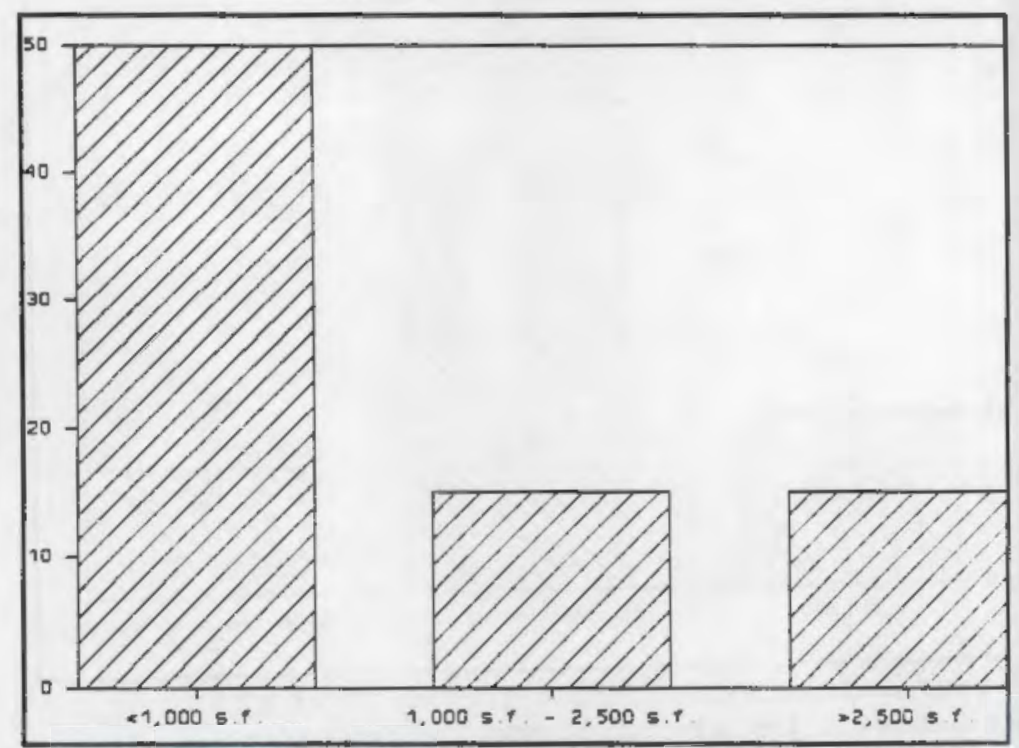

Figure 4. University Test Facilities-Controllable Environment (percent of respondents) 


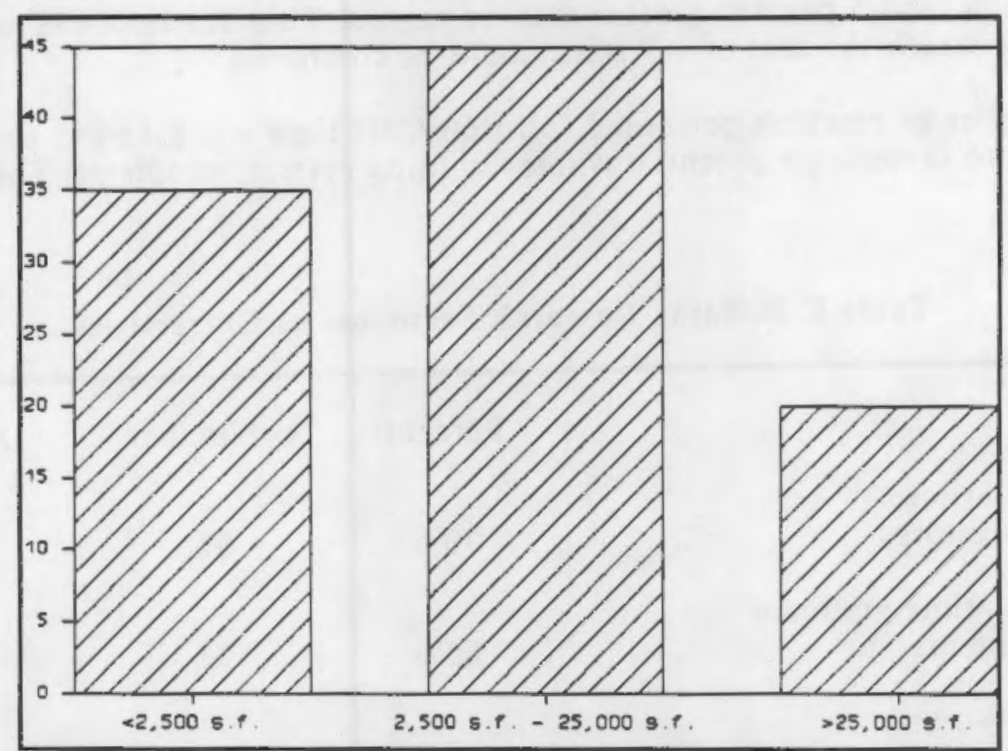

Figure 5. University Test Facilities-Standard Laboratory Space (percent of respondents)

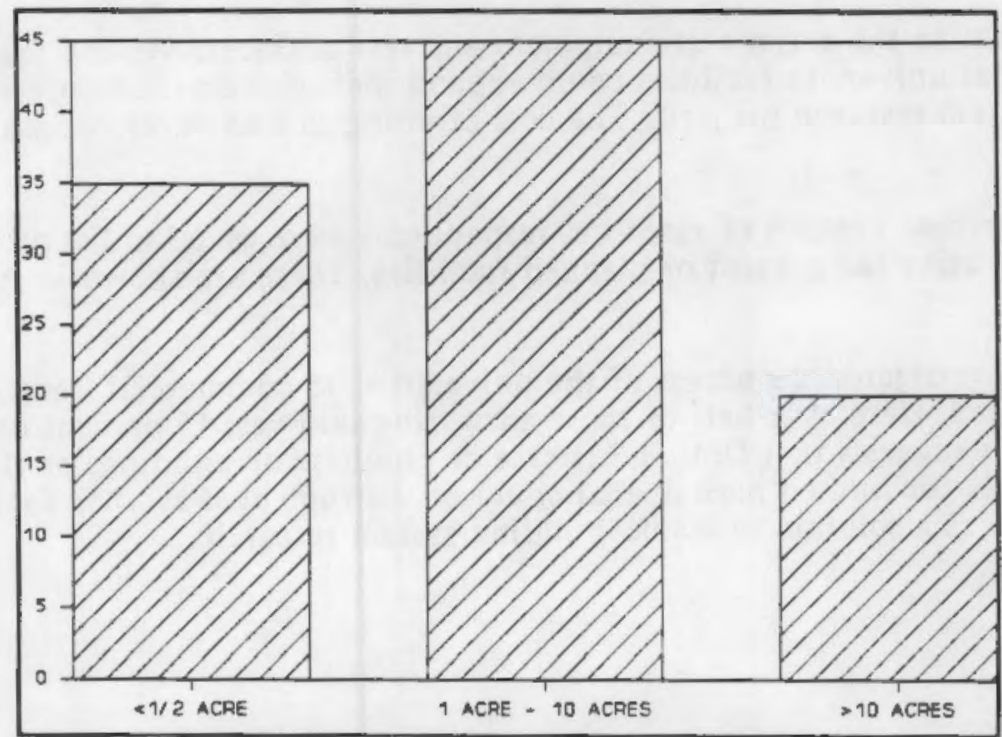

Figure 6. University Test Facilities-Open Area (for erecting buildings or assemblies) (percent of respondents) 


\section{Valug of UntVersity factuities and Equipment and Number of Personnel}

Thirty-five percent of the universities have facilities valued at less than $\$ 1$ million; 45 percent, \$1 million to $\$ 5$ million, and 5 percent greater than $\$ 5$ millon. This question was asked to establish a benchmark against which the cost of a WBSIL could be compared.

Likewise, the number of research personnel full time/part time was asked to determine the pool of talent available to investigate potential whole-building systems problems. These divided as shown in Table I.

Table I. Building Research Personnel at Universities

\begin{tabular}{lccc}
\hline & Percent & Number & Average \\
$\begin{array}{l}\text { Full-time } \\
\text { professors }\end{array}$ & $70 \%$ & 67 & 4.7 \\
$\begin{array}{l}\text { Full-time graduate } \\
\text { assistants }\end{array}$ & $65 \%$ & 95 & 7.3 \\
$\begin{array}{l}\text { Part-time } \\
\text { professors }\end{array}$ & $55 \%$ & 26 & 2.36 \\
$\begin{array}{l}\text { Part-time graduate } \\
\text { assistants } \\
\begin{array}{l}\text { Technical support } \\
\text { staff }\end{array}\end{array}$ & $35 \%$ & 28 & 4 \\
\hline
\end{tabular}

A question to determine the major test equipment and test chambers yielded the list in Appendix B. This indicates that university facilities could expand their equipment complement to include whole-building system research projects. The cost of doing this however, would require further investigation.

To determine the present breadth of research, respondents were asked to list projects completed, current, and future using the present or planned facilities. These are shown in Appendixes C, D, and $E$.

Another question investigated the access of the universities to commercial lease/buy space that could be instrumented. Here over half of those answering said yes; 15 percent no. Thirty percent did not answer. This suggests that Option 3 (Lease or purchase of buildings or floors in commercial buildings for limited periods that could be instrumented as a lab facility) while useful, was not seen as a solution to whole-building system research. 


\section{MAJOR SUPPORTERS OF RESEARCH}

Respondents were asked to cite sponsors and level of support for their research. This is shown in Table II.

Table II. Research Sponsors and Level of Support

\begin{tabular}{|c|c|c|c|c|}
\hline Sponsor & $\begin{array}{l}\text { Percent of } \\
\text { Support }\end{array}$ & $\begin{array}{l}\text { Amount of } \\
\text { Support (Aver) }\end{array}$ & $\begin{array}{l}\text { Amount of } \\
\text { High }\end{array}$ & $\begin{array}{c}\text { Support } \\
\text { Low }\end{array}$ \\
\hline Private & $20 \%$ & 80,000 & 250,000 & 10,000 \\
\hline University & 30 & 35,000 & 50,000 & 20,000 \\
\hline State & 40 & 197,000 & 500,000 & 10,000 \\
\hline Public & 35 & 237,000 & 700,000 & 10,000 \\
\hline \multicolumn{5}{|c|}{$\begin{array}{l}\text { 1. Not all respondents listed amounts or percentages. This table is a calculated } \\
\text { componite and must be regarded as a guide only, not actuai figures. }\end{array}$} \\
\hline
\end{tabular}




\section{IMPORTANCE OP OPTIONS 1-4}

The four options laid out by the PNL panel, discussed above, were rated by respondents concerning the need and amount of fuel reduction that could be realized if a whole-building facility were established-as well as the research that could be accomplished.

Option 1. A center that would primarily coordinate information about whole-building system integration with minimal or no test facilities.

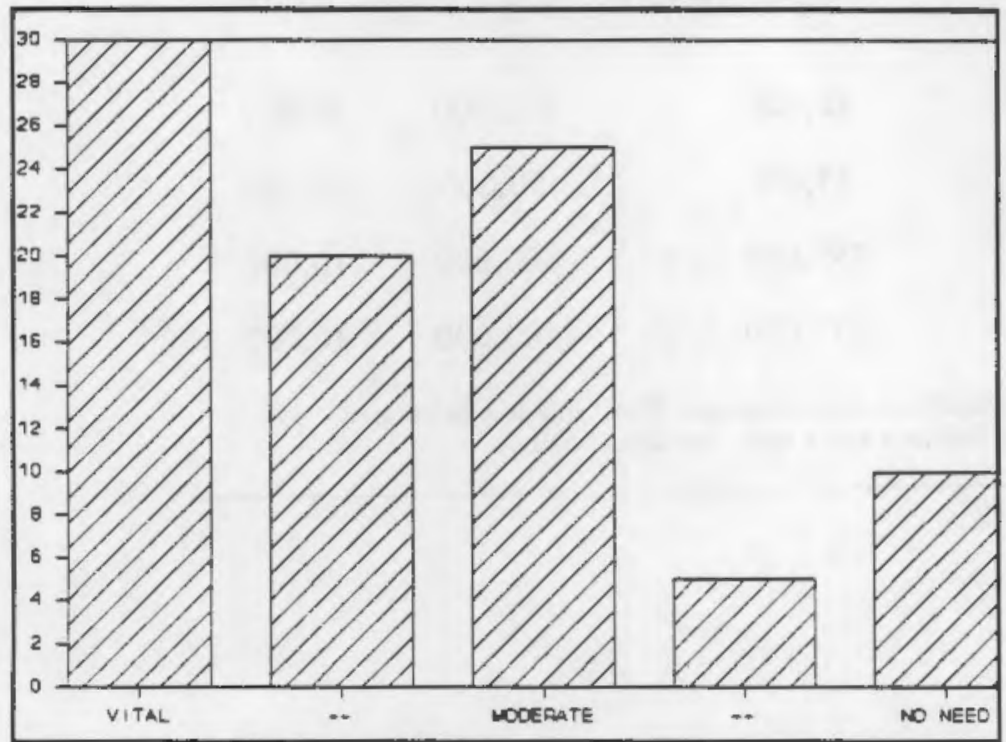

Thirty percent of the respondents identified this option as "vital." See Figure 7. Their perceptions about potential fossil fuel savings in commercial buildings (assuming that sector now consumes 12 quads annually) are shown in Table IIIa.

Figure 7. Need for Option 1

Table IIIa. Option 1 Fuel Savings

Respondents Rating Option 1 Vital

$20 \%$

$5 \%$
Perceived Percent of Fossil Fuel Savings Based on 12 Quads Energy Consumption

$50 \%$ to $25 \%$

$25 \%$ to $10 \%$

Less than $5 \%$

In addition, other respondents who did not rate this option as vital offered their perceptions, shown in Table IIIb, of savings that could be achieved if the option were implemented. 
Table IIIb. Option 1 Fuel Savings

\section{Respondents Not Rating Option 1 Vital}

$20 \%$
Perceived Percent of Fossil Fuel Savings Based on 12 Quads Energy Consumption

$10 \%$ to $5 \%$

Respondents of fered the following comments to the importance to whole-building related research findings that only such a facility could verify.

Would provide "System performance and modeling."

"With proper direction and cooperation such an approach could be an ideal approach, but lack of coordination/cooperation and follow-through always renders such approaches as less than adequate. They leave many ends untied."

Investigate "ventilation and thermal recovery."

"Isn't this research being done by NBS?"

"There is a need to have some coordination of efforts to determine trends in research results."

"This is a political decision, we can make it anything we want to."

Investigate "adaptive optimal control results in actual buildings."

Option 2. A three-story, 30,000 s.f. facility within an environmental chamber that could be removed to expose test floors to the local climate conditions.

Fif teen percent of the respondents identified this option as "vital." Table IVa indicates their perceptions of the associated fuel savings in commercial buildings.

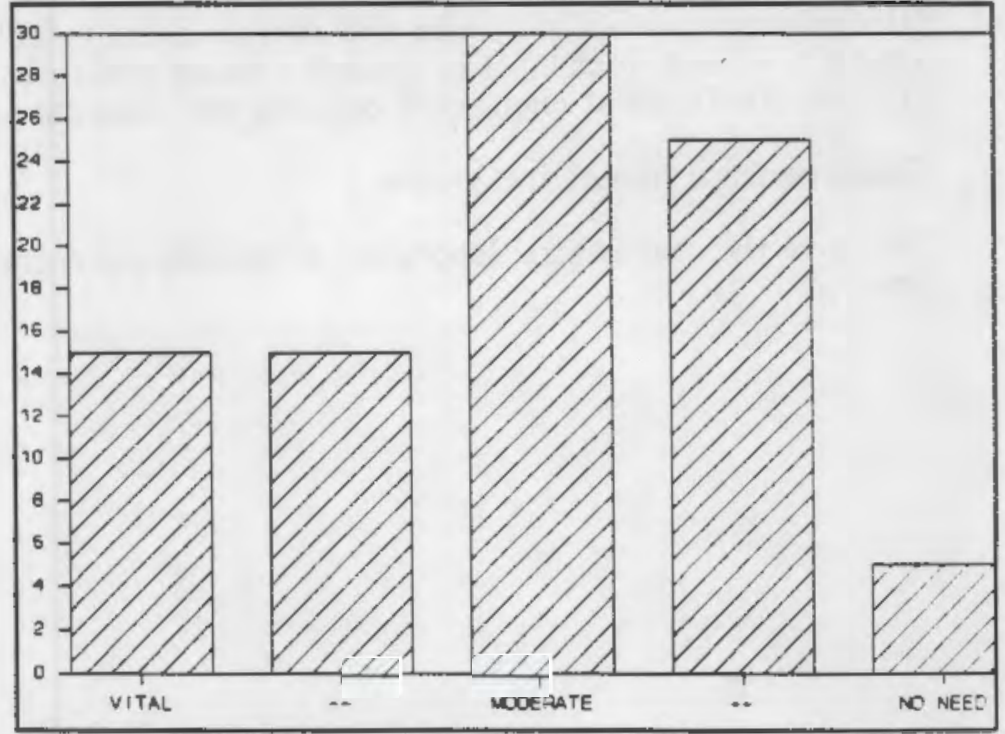

Figure 8. Need for Option 2 
Table IVa. Option 2 Fuel Savings

\begin{tabular}{cc}
\hline $\begin{array}{l}\text { Respondents Rating } \\
\text { Option } 2 \text { Vital }\end{array}$ & $\begin{array}{l}\text { Perceived Percent of Fossil Fuel Savings } \\
\text { Based on 12 Quads Energy Consumption }\end{array}$ \\
$5 \%$ & $50 \%$ to $25 \%$ \\
$5 \%$ & $25 \%$ to $10 \%$ \\
$5 \%$ & Less than $5 \%$ \\
\hline
\end{tabular}

In addition, other respondents who did not rate this option as vital offered their perceptions, shown in Table IVb, of the savings that could be achieved if the option were implemented.

Table IVb. Option 2 Fuel Savings

$\begin{array}{ll}\text { Respondents Not Rating } & \begin{array}{l}\text { Perceived Percent of Fossil Fuel Savings } \\ \text { Option } 2 \text { Vital }\end{array} \\ \text { Based on } 12 \text { Quads Energy Consumption }\end{array}$

$15 \%$

$20 \%$

$50 \%$ to $25 \%$

$25 \%$ to $10 \%$

$5 \%$

$10 \%$ to $5 \%$

Respondents offered the following comments on the importance to whole-building research findings that only such a facility could verify.

This facility could "study energy savings using sufficient energy storage to of fset heating and cooling loads in moderate weather. ... Detailed control conditions to document 1) influence of infiltration, 2) ventilation adequacy, 3 ) building energy modeling."

"Unfortunately it will take time and another crisis to make changes. The facilities could verify 1) effects in changes of control systems strategies, 2) effects of changes in HVAC systems, 3 ) effects of changes of building envelope characteristics."

Could perform "theoretical studies."

"We have rigorous natural laboratory conditions [in Alaska] which could benefit this concept." 
Option 3. Lease/purchase of buildings or floors in commercial buildings that could be instrumented and staffed by universities and private and federal laboratories.

Ten percent of the respondents identified Option 3 as "vital."

Table $\mathrm{V}$ indicates their perceptions of the associated fossil fuel savings in commercial buildings.

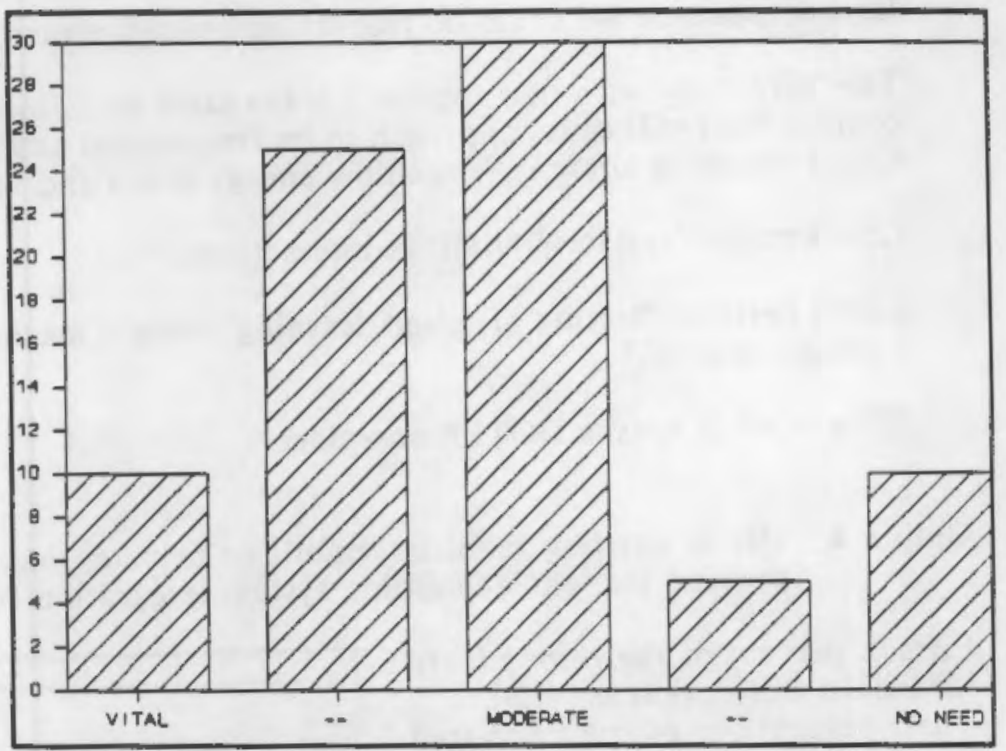

Figure 9. Need for Option 3

Table Va. Option 3 Fuel Savings

\begin{tabular}{cc}
\hline $\begin{array}{l}\text { Respondents Rating } \\
\text { Option } 3 \text { Vital }\end{array}$ & $\begin{array}{c}\text { Perceived Percent of Fossil Fuel Savings } \\
\text { Based on 12 Quads Energy Consumption }\end{array}$ \\
$10 \%$ & $25 \%$ to $10 \%$ \\
\hline
\end{tabular}

In addition, other respondents who did not rate Option 3 as vital offered their perceptions, shown in Table $\mathrm{Yb}$, of the savings that could be achieved if the option were implemented.

Table Vb. Option 3 Fuel Savings

\begin{tabular}{cc}
\hline $\begin{array}{c}\text { Respondents Not Rating } \\
\text { Option } 3 \text { Vital }\end{array}$ & $\begin{array}{l}\text { Perceived Percent of Fossil Fuel Savings } \\
\text { Based on } 12 \text { Quads Energy Consumption }\end{array}$ \\
$5 \%$ & $50 \%$ to $25 \%$ \\
$15 \%$ & $25 \%$ to $10 \%$ \\
$5 \%$ & $10 \%$ to $5 \%$ \\
\hline
\end{tabular}


Respondents offered the following comments to the importance to whole-building related research findings that only such a facility could verify.

In this approach we could do real "system performance and modeling."

The "difficulty with this approach is the same as delineated in \#1. Lack of long term commitment will cause approach to be fragmented and less controlled than desirable." Could "measure alternative window energy losses and verify ASHRAE models."

Could model "systems/buildings interactions."

Could perform "testing of a 'self learning' control machine for general application to building control."

"This is what Alaska DOTPF now does."

Option 4. Use of existing facilities, public or private, that could be enhanced if necessary to provide the whole-building system integration features needed.

Fif teen percent of the respondents identified this option as "vital."

Their perceptions of the associated fossil fuel savings in commercial buildings are shown in Table VIa.

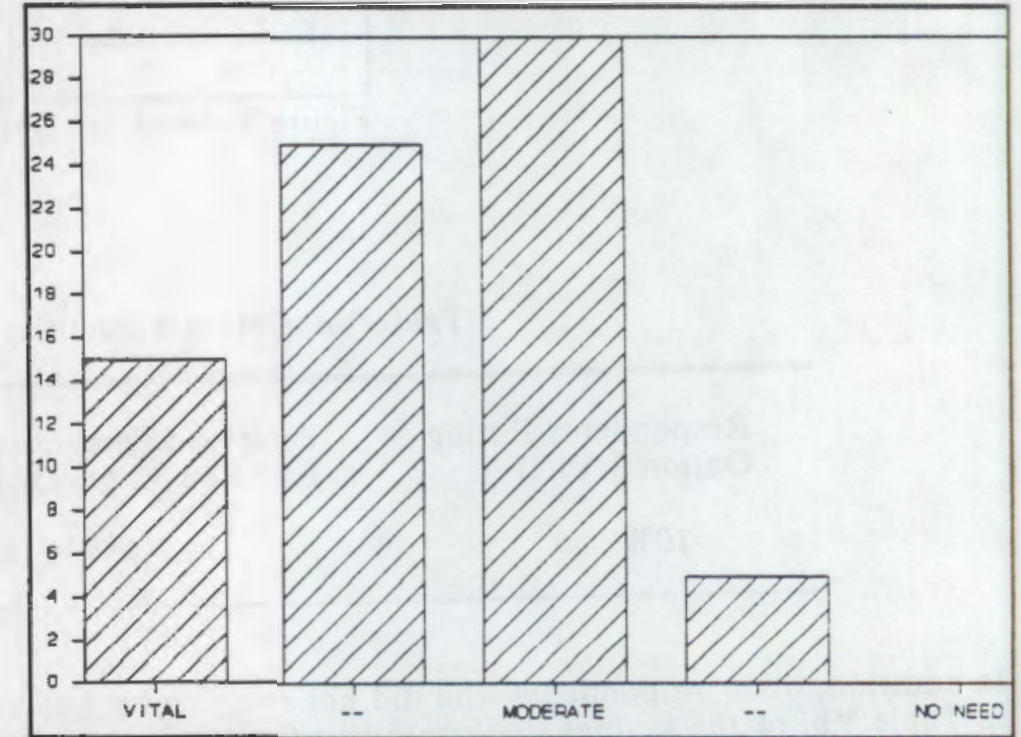

Figure 10. Need for Option 4

Table VIa. Option 4 Fuel Savings

Respondents Rating Option 4 Vital

$15 \%$
Perceived Percent of Fossil Fuel Savings Based on 12 Quads Energy Consumption

$25 \%$ to $10 \%$ 
In addition, other respondents who did not rate this option as vital offered their perceptions, shown in Table VIb, of the savings that could be achieved if the option were implemented.

Table VIb. Option 4 Fuel Savings

\begin{tabular}{cc}
$\begin{array}{l}\text { Respondents Not Rating } \\
\text { Option } 4 \text { Vital }\end{array}$ & $\begin{array}{l}\text { Perceived Percent of Fossil Fuel Savings } \\
\text { Based on } 12 \text { Quads Energy Consumption }\end{array}$ \\
$5 \%$ & $50 \%$ to $25 \%$ \\
$20 \%$ & $25 \%$ to $10 \%$ \\
$10 \%$ & $10 \%$ to $5 \%$ \\
$5 \%$ & Less than $5 \%$ \\
\hline
\end{tabular}

Respondents of fered the following comments to the importance to whole-building related research findings that only such a facility could verify.

The "difficulty with this approach is the same as delineated in \#1. Lack of long-term commitment will cause approach to be fragmented and less controlled than desirable." Would provide "system performance and modeling.

"Depends on how it used. Could result or be anything." 


\section{Appendix A - Survey Form}

\section{WHOLE-BUILDING SYSTEMS INTEGRATION LABORATORY}

\section{SURVey PuRPose}

We would like you to complete this survey because of your interest in building energy conservation and efficiency research. Your response is important. It will help shape the Department of Energy's decision to provide a whole-building systems integration laboratory. If founded, the laboratory will investigate energy flows arising from the interactions of building systems design and use.

Your response is needed by mid June to be included in a report to DOE. The survey results will be reported in ACEC/RMF publications.

\section{INSTRUCTIONS}

This survey is easy to complete. Most questions require a check-the-appropriate-box type of answer. A comment line is included if you wish to express an opinion not reflected by the check choices. Please feel free to add this important "flavoring."

\section{BACKGROUND INFORMATION}

The whole-building systems integration laboratory feasibility study, now underway through the summer, was initiated by the Department of Energy to determine the programmatic feasibility of constructing a laboratory dedicated to the investigation of commercial whole-building and system-integration issues. Commercial buildings account for over 15 percent of the fossil fuel energy used in the United States.

A committee of two dozen individuals (listed on the next page) from the private sector, universities, and federal laboratories is providing primary information to Battelie/Pacific Northwest Laboratory, which is conducting the feasibility study.

The working hypothesis is that there is a need for specific facilities and coordination activities to increase the effectiveness and use of completed, ongoing, and future building energy research.

The facility could work in two distinct areas: testing known unknowns to incrementally improve existing building assemblies and concepts and testing unknown unknowns to develop new building concepts. In the latter case this may be working towards a "zero-fossil-fuels" integrated systems building.

If determined to be needed, the facility would be administered by DOE's Office of Buildings and Community Systems, most likely through the federal laboratory system. The location is undetermined, although the laboratories most active in building research are located in Washington state, California, Tennessee, Colorado, New Mexico, and New York. 
The committee has proposed a number of alternative schemes to achieve the envisioned purpose, based on the pros and cons in terms of money, time, critical questions, effective results, increase in U.S. competitiveness and professionalism.

The alternative schemes are:

1. A center that would primarily coordinate information about whole-building system integration with minimal or no test facilities. The center would rely on the third and fourth schemes below. Test facilities - scheme $2-$ is an example, would be added as critical research questions became focused.

2. A three-story, 30,000 s.f. facility within an environmental chamber that could be removed to expose test floors to the local climate conditions.

3. Lease or purchase of buildings or floors in commercial buildings around the country for limited periods that could be instrumented and staffed by universities and private and federal laboratories and used as a lab facility.

4. Use of existing facilities, public or private, that could be enhanced if necessary to provide the whole-building system integration features needed.

Your participation is important. If you have any questions please call or telefax:

Jack Warner

ACEC Research \& Management Foundation

202/347-7474 voice

202/898-0068 fax 
1. Estimate the total value of building energy related research projects that your department performs annually. (Check one range)
[ I Less than $\$ 250,000$
(1) $\$ 250,000-\$ 500,000$
[] $\$ 500,000-\$ 1$ million
[] Over $\$ 1$ million

2. Estimate the total value of bullding energy related research projects that your university performs ennually. (Check one range)
[ ] Less than $\$ 50,000$
[ ] $\$ 50,000-\$ 1$ million
[] \$1 million - \$5 million
[ ] Over $\$ 5$ million

3. Description of physical facility. Your existing or proposed test facilities that could be used for whole-building systems testing. If you have a written description please return it with this questionnaire. We have:

Controlled environment testing area
[] < 1000 s.f.
[ ] 1000 to 2,500 s.f.
[1]>2,500 s.f.

Controllable environment testing area
[ ] < 1000 s.f.
[ ] 1000 to 2,500 s.f.
[ ] > 2,500 s.f.

Standard laboratory space
[ ] $<2500$ s.f.
[ ] 2,500 to 25,000 s.f.
[ ] > 25,000 s.f.

Test facility open area (for erecting buildings or assemblies)
[] $<1 / 2$ acre
[ ] 1 to 10 acres
[ ] $>10$ acres

Access to commercial lease/buy space that could be instrumented? Yes No

- Estimated total replacement value of facility and equipment:
[] \$1 million
[] $\$ 1$ million - $\$ 5$ million [] $>\$ 5$ millon

- Number of research personnel full time/part time
Full-time professors
Full-time graduate assistants
Part-time professors
Part-time graduate assistants
Technical support staff

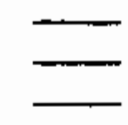

- Major test equipment/test chambers (designate $F=$ Fixed, $P=$ Portable)

[]

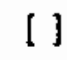

[ ] 


\section{Questions about projects completed, current, and future projects using the facilities or planned facilities:}

List funding level and brief title of recently completed projects (up to three)

1.

2.

3.

List funding level and title of current projects (up to three)

1.

2.

3.

List funding level and brief title of future projects (up to three)

1.

2.

3.

Major users/supporters of facilities:

\%] Private

Approximate Dollar volume

\%] University

\%] Public State

\%] Public Federal

$=100 \%$

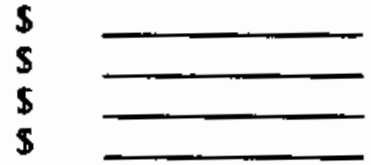

5. Your Thoughts, Please. Expression of geed for a whole-building systems testiog facility. Rate the four options:

1. A center that would primarily coordinate information about whole-building system integration with minimal or no test facilities. The center would rely. on the third and fourth schemes. Test facilities - scheme 2 is an example

- would be added as critical research questions became focused.

[ ] Vital [] [] Moderate need [ [ ] [] No need

- If you identify this option as "vital," what reduction in fossil fuel consumption would you estimate the research would result in over the next I0 years? Commercial buildings now consume approximately 12 quads.

[ ] Greater than $50 \%$

[ ] $25 \%$ to $10 \%$

[] $50 \%$ to $25 \%$

[] $10 \%$ to $5 \%$

[ ] Less than $5 \%$

- Please identify an important whole-building-related research finding that only such a facility could verify: 
2. A three-story, 30,000 s.f. facility within an environmental chamber that could be removed to expose test floors to the local climate conditions.
[] Vital
[]
[ ] Moderate need
[ ]
(] No need

- If you identify this option as "vital," what reduction in fossil fuel consumption would you estimate the research would result in over the next 10 years?
[1 Greater than $50 \%$
[] $50 \%$ to $25 \%$
[] $25 \%$ to $10 \%$
[] $10 \%$ to $5 \%$
[] Less than $5 \%$

- Please identify an important whole-building-related research finding that only such a facility could verify:

3. Lease/purchase of buildings or floors in commercial buildings around the country that could be instrumented and staffed by universities and private and federal laboratories.
[ ] Vita]
[]
[ ] Moderate need
[ ] [ ] No need

- If you identify this option as "vital," what reduction in fossil fuel consumption would you estimate the research would result in over the next 10 years?
[] Greater than $50 \%$
[] $50 \%$ to $25 \%$
[] $25 \%$ to $10 \%$
[] $10 \%$ to $5 \%$
[] Less than $5 \%$

- Please identify an important whole-building-related research finding that only such a facility could verify:

4. Use of existing facilities, public or private, that could be enhanced if necessary to provide the whole-building system integration features needed.
[ ] Vital
[]
[ ] Moderate need
[ ]
[ ] No need

- If you identify this option as "vital," what reduction in fossil fuel consumption would you estimate the research would result in over the next 10 years?
[ ] Greater than $50 \%$
[] $50 \%$ to $25 \%$
[] $25 \%$ to $10 \%$
[ ] $10 \%$ to $5 \%$
[] Less than $5 \%$

- Please identify an important whole-building-related research finding that only such a facility could verify:

Interest in whole-building systems integration research:

[ ] Very [] Moderately [ ] Keep me informed [] Not Interested

My knowledge/expertise in whole-building systems integration research is:
[] Expert
[ ] Journeyman
[ ] Apprentice
[ ] Beginner 


\title{
Appendix B - Equipment Available at Universities*
}

\author{
Air flow loop $2500 \mathrm{cfm} 4$ coils + instrumentation \\ Air-to-air heat exchange test facility (being built) \\ Anechoic chamber \\ Blower door - portable \\ C177 guarded hot plate \\ C976 calibrated hot box \\ Complete shop facility \\ Completely instrumented buildings, (4) approx. 3,000 sq. ft. each \\ Completely instrumented test houses (2) \\ Completely instrumented mobile homes (2) \\ Controllable rooms $2-8^{\prime} \times 12^{\prime} \times 8^{\prime}$ \\ Data acquisition for testing buildings - portable \\ Data acquisition system \& computers \\ Data acquisition systems - portable \\ Energy research house (being sold this summer) \\ Engineering research center, high bay area of approximately $10,000 \mathrm{sq}$. Ft. \\ Environmental chambers (2) approximately 4 tons heating or cooling each \\ Fan testing equipment \\ Fan test facility \\ Guarded hot box \\ Heat pump test \\ Heat pump \\ Heat pump test facility \\ Hot box/cold box test chambers \\ HVAC Test facilities \\ Instrumentation - portable \\ Laboratory quality portable energy audit \\ Large area low speed wind tunnel \\ Low speed wind tunnel for building tests \\ Materials laboratory \\ Natural convection testing chamber \\ Photovoltaic operated HVAC system \\ Plumbing/piping test facility for high rise buildings \\ Psychometric chambers \\ Reverberation chamber \\ Screw compressor test bed \\ Solar thermal collectors - portable \\ Solar calorimeter \\ Solar radiation meas. Stations \\ Solar calorimeter \\ Thermal energy storages \\ Weather station \\ Window guarded hot box (being designed) - portable
}

\footnotetext{
All equipment is fixed unless otherwise noted
} 
Cold air distribution systems, $\$ 70,000$

Development of three fluid heat pump system, $\$ 25,000$

DOE industrial energy audits, $\$ 100,000$

Energy analysis and diagnostic center, $\$ 350,000$

Environmental chamber design, $\$ 10,000$

Field testing of heat pump system ( $\$$ n.avail.)

Field testing of air conditioner systems (\$ n.avail.)

Florida building code revision, $\$ 150,000$

Heat transfer studies in military repair facilities, $\$ 75,000$

Ice storage, $\$ 20,000$

Interzonal heat transfer studies, $\$ 75,000$

Material characteristic determination, $\$ 10,000$

Microcomputer energy analyses program comparison, $\$ 15,000$

Modeling studies (IEA), $\$ 100,000$

NBS/DOE Window thermal measurements, $\$ 50,000$

Optimal control studies, $\$ 100,000$

Photovoltaic operated heat pump system; photovoltaic assistance heating

system; solar thermal HVAC (funding for all three), $\$ 700,000$

Radiant barrier study, $\$ 50,000$

Stratified environments, $\$ 100,000$

Transient moist air coil, $\$ 10,000$

Appendix D - Brief Title Of Current Projects And Funding Level

A study on photovoltaic powered cooling, $\$ 185,000$

Development of ice-forming heat pump, $\$ 6,000$

DOE industrial energy audits, $\$ 100,000$

ASHRAE Manual Of Heat Transmission Coefficients, $\$ 50,000$

ASHRAE/UMASS Air-to-air heat exchanger research, $\$ 15,000$

Optimization of cooling coil design ( $\$$ n.avail.)

Integrated expert control systems for intelligent buildings ( $\$$ n.avail.)

Humidity control systems, honeywell ( $\$$ n.avail.)

Direct contact cool storage systems, $\$ 15,000$

Energy auditing computer program, $\$ 10,000$

Heat pump/hydronic radiant ceiling, $\$ 50,000$

Room circulations studies, $\$ 50,000$

Desorption humidity control, $\$ 60,000$

Florida building code compliance study, $\$ 25,000$

Low mass and high mass building performance (total [unding for two), $\$ 150,000$

A/I Applications to building control, $\$ 30,000$

Desiccant cooling research, $\$ 100,000$

Energy conservation in commercial buildings, $\$ 55,000$ 
Appendix E - Brief Title Or Future Projects And Funding Level

\author{
Air-to-air heat exchanger research, $\$ 50,000$ \\ Commercial building energy analysis \& diagnostic program, $\$ 100,000$ \\ DOE Window thermal analysis, $\$ 150,000$ \\ DOE Industrial energy audits (continuing project), $\$ 100,000$ \\ Field tests of building equipment components ( $\$$ n.avail.) \\ - Heat pump and other building component testing (\$ n.avail.) \\ Intelligent buildings research, $\$ 50,000$ \\ Modeling studies, $\$ 80,000$ \\ Running stream biological/environmental response, $\$ 100,000$
}




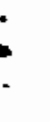


PNL-6986

UC -350

\section{DISTRIBUTION}

No. of

Copies

OFFSITE

2 DOE/Office of Scientific and Technical Information

M. L. Bailey

U.S. Department of Energy

Forrestal Building, CE-131 5E-098

1000 Independence Avenue $5 H$

Washington, DC 20585

J. J. Boulin

U.S. Department of Energy

Forrestal Building, CE-131 5E-098

1000 Independence Avenue SW

Washington, DC 20585

J. P. Millhone

U.S. Department of Energy

Forrestal Building, CE-131 5E-098

1000 Independence Avenue SW

Washington, DC 20585

J. A. Smith

U.S. Department of Energy

Forrestal Building, CE-I31 5E-098

1000 Independence Avenue SW

Washington, DC 20585

J. D. Rivera

D\&R Internationa T

962 Wayne Avenue

Silver Spring, MD 20910
No. of

Copies

ONSITE

DOE Richland Operations office

D. E. Collantes, A5-90

14 Pacific Northwest Laboratory

D. B. Crawley (3), K5-12

M. K. Drost, K5-12

B. M. Johnson, K5-12

T. J. Secrest (3), K5-12

Publishing Coordination

Technical Report Files (5) 
